\title{
HUBUNGAN PANJANG TUNGKAI DAN DAYA LEDAK OTOT TUNGKAI DENGAN HASIL LARI SPRINT 100 METER
}

\author{
Yahya Eko Nopiyanto \\ Universitas Bengkulu, email: yahyaekonopiyanto@unib.ac.id \\ Syafrial \\ Universitas Bengkulu \\ Santun Sihombing \\ Universitas Bengkulu
}

\begin{abstract}
Abstrak
Tujuan penelitian ini adalah untuk mengetahui hubungan panjang tungkai dan daya ledak otot tungkai dengan hasil lari sprint 100 meter pada siswa putra kelas VII di SMP Negeri 1 Indralaya. Metode yang digunakan dalam penelitian ini adalah metode korelasi. Populasi dalam penelitian ini adalah siswa putra kelas VII SMP Negeri 1 Indralaya yang berjumlah 91 siswa, sampel penelitian ini berjumlah 91 siswa. Teknik yang digunakan untuk mengumpulkan data panjang tungkai adalah antropometer, power otot tungkai menggunakan tes vertical jump, sedangkan hasil lari menggunakan tes lari sprint 100 meter. Teknik analisis data menggunakan uji korelasi Pearson Product Moment Corelation. Hasil penelitian ini menunjukkan bahwa: (1) adanya hubungan panjang tungkai dengan hasil lari sprint 100 meter dengan nilai $r-0,05$. (2) adanya hubungan daya ledak otot tungkai dengan hasil lari sprint 100 meter dengan nilai $r-0,09$. (3) adanya hubungan panjang tungkai dan daya ledak otot tungkai dengan hasil lari sprint 100 meter dengan nilai r 0,27. Berdasarkan hasil penelitian tersebut dapat disimpulkan bahwa ada hubungan yang tidak signifikan pada panjang tungkai dan daya ledak otot tungkai dengan hasil lari sprint 100 meter.
\end{abstract}

Kata kunci: panjang tungkai, daya ledak otot tungkai, sprint

\begin{abstract}
The purpose of this study was to determine the relationship between leg length and leg muscle explosive power with the results of 100-meter sprints in male students of class VII in SMP Negeri 1 Indralaya. This research employed the corelational method design. This research was population research. All subjects in the population were included in this research with a total of 91 male students. The statistical analysis the Pearsons' Product Moment Corelation statistical technique was employed. The research findings revealed that: (1) there was a relationship between leg length and the results of 100-meter sprints with a value of $r-0.05$. (2) there was a relationship between leg muscle power and the results of 100-meter sprints with a value of $r$ 0.09. (3) there was no significant a relationship between leg length and leg muscle power with the results of 100 -meter sprints with a value of $\mathrm{r} 0.27$.
\end{abstract}

Keywords: leg length, leg muscle explosive power, sprints 


\section{PENDAHULUAN}

Lari merupakan gerakan maju untuk memindahkan badan dengan secepatcepatnya, kedua kaki ada saat melayang dan tidak menempel ditanah atau lantai. Dalam dunia atletik internasional, perlombaan lari jarak pendek sering disebut sebagai sprint ( lari jarak pendek) atau dash. Nomor lari jarak pendek yang diperlombakan pada event internasional, jika diadakan di lapangan terbuka (outdoor) meliputi nomor lari 100 meter, 200 meter, dan $\mathbf{4 0 0}$ meter. Adapun lari jarak pendek yang dilaksanakan di lapangan tertutup (indoor) adalah lari 50 meter, 60 meter, 200 meter, 400 meter (Adi, 2008).

Pelari sprint harus dicari atlet yang sebagian besar memiliki otot putih atau fast tuwis, karena seorang pelari sprint, selain diperlukan kecepatan tinggi juga diperlukan jarak langkah, kekuatan, power otot tungkai, frekuensi langkah, koordinasi teknik, kelentukan (flexsibility), dan daya tahan anaerobik, kesemuanya merupakan komponen yang harus dipenuhi oleh seorang pelari sprint, untuk menghasilkan kecepatan yang tinggi (Sukirno, 2012).

Unsur gerak dalam lari terdiri dari (1) gerakan tungkai (bagian tubuh mulai dari sendi panggul ke bawah yaitu paha, tungkai bawah, dan kaki, (2) gerakan lengan (lengan atas, lengan bawah, dan tangan), (3) sikap badan, dan (4) koordinasi yang selaras dari semua unsur gerak tersebut (Nadisah, 1991). Gerakan tungkai merupakan modal utama agar seorang pelari dapat melaju, mulai dari garis keberangkatan hingga garis akhir. Gerakannya berupa pengulangan dari setiap tahap gerakan yang sudah dilakukan. Seorang olahragawan yang memiliki proporsi badan tinggi biasanya diikuti dengan ukuran tungkai yang panjang. Ukuran tungkai yang panjang akan memberikan keuntungan dalam jangkauan langkah.

Pelari cepat (sprinter) harus mampu menghasilkan gaya dorong ke belakang sebesar mungkin selain itu pada saat mendorong tanah atau menjejakkan kakinya ke lintasan lari, tungkai harus benar-benar dalam keadaan lurus, sehingga gaya dorong ke belakang yang dihasilkan secara keseluruhan dapat diubah menjadi gerakan maju ke depan dengan kecepatan gerak yang tinggi. Untuk mengubah gaya dorong ke belakang menjadi gerakan ke depan di butuhkan power otot tungkai. Power adalah kemampuan otot untuk mengerahkan kekuatan maksimal dalam waktu yang sangat cepat (Harsono, 1988).

Berdasarkan hasil observasi dan wawancara dengan guru penjaskes SMP Negeri 1 Indralaya diketahui bahwa kemampuan siswa dalam melakukan lari sprint 100 meter masih kurang hal ini dapat dilihat dari hasil tes yang dilakukan oleh guru, dari hasil tes tersebut diketahui siswa yang menempuh waktu 16,5 detik $40 \%$ sedangkan $60 \%$ siswa melakukan lari sprint dengan waktu lebih dari 16,5 detik. Dari hasil pengamatan di lapangan pada waktu tes siswa belum paham mengenai start yang akan digunakan, siswa belum bisa mengatur jangkauan langkah dalam melakukan lari sprint 100 meter, tolakan kaki ketika lari kurang maksimal.

Peneliti menyimpulkan bahwa panjang tungkai dan daya ledak otot tungkai mempunyai peranan penting untuk mendapatkan hasil lari sprint 100 meter yang optimal. Namun panjang tungkai dan besarnya daya ledak otot tungkai siswa putra kelas VII belum diketahui secara pasti, hal inilah yang membuat peneliti tertarik untuk membuktikan apakah ada hubungan panjang tungkai dan daya ledak otot tungkai dengan hasil lari sprint 100 meter. Sehingga peneliti mengangkat judul penelitian "hubungan panjang tungkai dan daya ledak otot tungkai dengan hasil lari sprint 100 meter siswa putra kelas VII di SMP Negeri 1 Indralaya"

\section{METODE}

Jenis penelitian yang digunakan dalam penelitian ini adalah penelitian korelasi. Rancangan penelitian yang digunakan dalam penelitian ini adalah desain korelasi (correlational design). Populasi dalam penelitian ini seluruh siswa putra kelas VII 
dengan jumlah 91 siswa putra. Teknik sampling yang digunakan dalam penelitian ini adalah total sampling. Jadi sampel yang digunakan pada penelitian ini sama dengan jumlah populasi yaitu 91 siswa putra. Hubungan $\left(X_{1}, Y\right)$ dan $\left(X_{2}, Y\right)$ merupakan hubungan atau korelasi linier sederhana, dapat dianalisis menggunakan Koefisien Korelasi Regresi Linier Sederhana Pearson Product Moment sebagai berikut :

$$
\begin{gathered}
r=\frac{n \sum_{i=1}^{n} x_{i} y_{i}-\left(\sum_{i=1}^{n} x_{i}\right)\left(\sum_{i=1}^{n} y_{i}\right)}{\sqrt{\left[n \sum_{i=1}^{n} x_{i}^{2}-\left(\sum_{i=1}^{n} x_{i}\right)^{2}\right]\left[n \sum_{i=1}^{n} y_{i}{ }^{2}-\left(\sum_{i=1}^{n} y_{i}\right)^{2}\right]}} \\
\text { Keterangan: } Y=\text { variabel } \mathrm{Y} \\
X_{\mathrm{i}}=\text { variabel } \mathrm{X}
\end{gathered}
$$

Hubungan $\left(X_{1}, X_{2}, Y\right)$ merupakan hubungan atau korelasi linier berganda, dapat dianalisis menggunakan Koefisien Korelasi Regresi Linier Berganda sebagai berikut: (Sudjana, 2005).

$$
R^{2}=\frac{a_{1} \sum_{i=1}^{n} y_{i} x_{1 i}+a_{2} \sum_{i=1}^{n} y_{i} x_{2 i}}{\sum_{i=1}^{n} y_{i}^{2}}
$$

dimana:

$Y_{1}=$ Lari sprint 100 meter

$X_{1}=$ Panjang tungkai

$X_{2}=$ Daya ledak otot tungkai

\section{HASIL DAN PEMBAHASAN}

\section{Hasil}

Hasil data yang dikumpulkan mengenai panjang tungkai diperoleh skor tertinggi yang dicapai sebesar $94 \mathrm{~cm}$, sedangkan skor terendah adalah sebesar 60 $\mathrm{cm}$, setelah data di analisis diperoleh harga rata-rata sebesar $77,73 \mathrm{~cm}$, modus $73,9 \mathrm{~cm}$ median $76,8 \mathrm{~cm}$ dan simpangan baku $6,31 \mathrm{~cm}$. Distribusi frekuensi variabel panjang tungkai dapat dilihat pada tabel berikut ini:

Tabel 1. Daftar Distribusi Frekuensi Panjang Tungkai

\begin{tabular}{c|c|c|c} 
No & Panjang Tungkai & $\mathrm{f}_{1}$ & $x_{1}$ \\
\hline 1 & $60-64$ & 1 & 62
\end{tabular}

\begin{tabular}{c|c|c|c}
2 & $65-69$ & 1 & 67 \\
\hline 3 & $70-74$ & 31 & 72 \\
\hline 4 & $75-79$ & 27 & 77 \\
\hline 5 & $80-84$ & 20 & 82 \\
\hline 6 & $85-89$ & 5 & 87 \\
\hline 7 & $90-94$ & 6 & 92
\end{tabular}

Hasil data yang dikumpulkan mengenai daya ledak otot tungkai diperoleh skor tertinggi yang dicapai $56 \mathrm{~cm}$, sedangkan skor terendah adalah sebesar $22 \mathrm{~cm}$. berdasarkan data tersebut di analisis diperoleh harga rata-rata sebesar $38,15 \mathrm{~cm}$, modus $32,9 \mathrm{~cm}$, median 36,2 $\mathrm{cm}$ dan simpangan baku sebesar $9,19 \mathrm{~cm}$. Distribusi frekuensi variabel daya ledak otot tungkai dapat dilihat pada tabel 2 berikut ini:

Tabel 2. Daftar Distribusi Frekuensi Daya Ledak Otot Tungkai

\begin{tabular}{c|c|c|c} 
No & $\begin{array}{c}\text { Power Otot } \\
\text { Tungkai }\end{array}$ & $\mathrm{f}_{2}$ & $x_{2}$ \\
\hline 1 & $22-26$ & 4 & 24 \\
\hline 2 & $27-31$ & 19 & 29 \\
\hline 3 & $32-36$ & 24 & 34 \\
\hline 4 & $37-41$ & 11 & 39 \\
\hline 5 & $42-46$ & 12 & 43 \\
\hline 6 & $47-51$ & 14 & 49 \\
\hline 7 & $52-56$ & 7 & 54
\end{tabular}

Hasil data yang dikumpulkan mengenai lari sprint 100 meter diperoleh skor tercepat yang dicapai 15,50 detik, sedangkan skor paling lambat adalah 32,71 detik Berdasarkan data tersebut di analisis diperoleh harga rata-rata sebesar 20,85 detik, modus 19,46 detik, median 19,83 detik dan simpangan baku sebesar 3,02 detik. Distribusi frekuensi variabel lari sprint 100 meter dapat dilihat pada tabel berikut ini:

Tabel 3. Daftar Distribusi Lari sprint 100 meter No Lari sprint $100 \quad f_{3} \quad x_{3}$ meter

\begin{tabular}{c|c|c|c}
1 & $15,50-17,96$ & 12 & 16,73 \\
\hline 2 & $17,97-20,43$ & 34 & 19,19 \\
\hline 3 & $20,44-22,90$ & 29 & 21,67 \\
\hline 4 & $22,91-25,37$ & 8 & 24,14 \\
\hline
\end{tabular}




\begin{tabular}{c|c|c|c}
\hline 5 & $25,38-27,84$ & 5 & 26,61 \\
\hline 6 & $27,85-30,31$ & 2 & 29,08 \\
\hline 7 & $30,32-32,78$ & 1 & 31,55
\end{tabular}

\section{Pembahasan}

\section{Hubungan Panjang Tungkai Dengan Hasil Lari Sprint 100 meter}

Hubungan panjang tungkai dengan lari sprint 100 meter dapat diinterpretasikan dengan mengukur koefisien korelasi $(r)$ nya. Besar koefisien korelasi antara panjang tungkai dengan lari sprint 100 meter adalah sebesar $r=$ - 0,05 atau 5\%, termasuk dalam kategori tingkat hubungan yang sangat lemah. Berarti ada hubungan antara panjang tungkai dengan lari sprint 100 meter pada siswa putra SMP Negeri 1 Indralaya meskipun kontribusinya kecil.

Sudjana (2005: 365) menyatakan "apabila harga $r$ bernilai negatif menyatakan adanya hubungan linier sempurna tak langsung antara $X$ dengan $Y^{\prime \prime}$. Ini berarti bahwa titik-titik yang ditentukan oleh $(X, Y)$ seluruhnya terletak pada garis regresi linier dan harga $X$ yang besar menyebabkan atau berpasangan dengan $Y$ yang kecil sedangkan harga $X$ yang kecil berpasangan dengan $Y$ yang besar. Penelitian ini harga $r$ bernilai negatif, dengan demikian jika siswa memiliki ukuran tungkai yang panjang, akan memberikan kontribusi terhadap kecepatan lari sprint 100 meter dengan baik. $\mathrm{Hal}$ itu disebabkan semakin panjang tungkai seseorang akan dikuti dengan jangkauan langkah yang semakin panjang sehingga waktu yang diperlukan untuk menempuh suatu jarak dalam lari sprint 100 meter akan semakin pendek.

Sampel pada penelitian ini bukan siswa yang mengikuti kegiatan ekstrakurikuler, saat penelitian terdapat beberapa siswa memiliki tungkai yang panjang namun kecepatan larinya masih lemah, beberapa siswa mempunyai ukuran tungkai yang panjang namun kurang bersungguh-sungguh saat lari sprint 100 meter. Faktor lain yang menyebabkan adalah kecepatan reaksi siswa pada saat start masih lemah, siswa sering terlambat berlari saat aba-aba yak selesai dan daya tahan an aerobik siswa masih rendah hal ini dapat dilihat setelah siswa melewati jarak lebih dari 50 meter kecepatan larinya berkurang.

Hasil penelitian ini menunjukkan bahwa panjang tungkai merupakan salah satu komponen guna meningkatkan kecepatan lari sprint 100 meter. Lari jarak pendek (sprint) adalah suatu cara lari dimana si atlet harus menempuh jarak dengan kecepatan yang semaksimal mungkin (Syarifudin dan Muhadi, 1992). Kecepatan berlari ditentukan oleh dua aspek, yaitu panjang langkah dan frekuensi langkah. Tungkai pada tiap individu mempunyai ukuran yang berbeda sehingga berpengaruh terhadap perbedaan kecepatan lari tiap individu. Sehingga semakin panjang tungkainya akan dapat diikuti dengan jangkauan langkah yang semakin panjang sehingga waktu yang diperlukan untuk menempuh suatu jarak dalam lari akan semakin pendek, dengan kata lain waktu tempuhnya menjadi lebih cepat dan energi yang dikeluarkan akan semakin sedikit, hal ini tentu akan memberikan keuntungan bagi pelari sprint 100 meter. Hasil $r=-0,05$ menunjukkan hubungan yang sangat lemah atau tidak signifikan antara panjang tungkai dengan lari sprint 100 meter.

\section{Hubungan Daya Ledak Otot Tungkai Dengan Hasil Lari Sprint $\mathbf{1 0 0}$ meter}

Hubungan daya ledak otot tungkai dengan lari sprint 100 meter dapat diinterpretasikan dengan mengukur koefisien korelasi ( $r$ ) nya. Besar koefisien korelasi antara daya ledak otot tungkai dengan lari sprint 100 meter adalah sebesar $r=-0,09$ atau 9\%, termasuk dalam kategori tingkat hubungan yang sangat lemah. Berarti ada hubungan antara daya ledak otot tungkai dengan lari sprint 100 meter pada siswa putra SMP Negeri 1 Indralaya meskipun kontribusinya kecil.

Sudjana (2005: 365) menyatakan "apabila harga $r$ bernilai negatif menyatakan adanya hubungan linier sempurna tak langsung 
antara $X$ dengan $Y^{\prime \prime}$. Ini berarti bahwa titik-titik yang ditentukan oleh $(X, Y)$ seluruhnya terletak pada garis regresi linier dan harga $X$ yang besar menyebabkan atau berpasangan dengan $Y$ yang kecil sedangkan harga $X$ yang kecil berpasangan dengan $Y$ yang besar.

Pada penelitian ini harga $r$ bernilai negatif, dengan demikian jika siswa memiliki daya ledak otot tungkai yang besar, maka waktu untuk menempuh lari sprint 100 meter akan kecil. Dengan kata lain daya ledak otot tungkai yang besar memberikan kontribusi terhadap kecepatan lari sprint 100 meter dengan baik. Sampel pada penelitian ini bukan siswa yang mengikuti ekstrakurikuler. Hal yang terjadi pada waktu penelitian beberapa beberapa siswa mempunyai daya ledak yang baik namun kurang bersungguh-sungguh saat lari sprint 100 meter, siswa memiliki daya ledak yang baik namun ketika mereka berlari hasilnya kurang memuaskan,. Faktor yang menyebabkan hal itu terjadi dapat terjadi adalah daya tahan an-aerobik yang masih rendah.

Hasil penelitian ini menunjukkan bahwa daya ledak otot tungkai merupakan salah satu komponen guna meningkatkan kecepatan lari sprint 100 meter. Harsono (1998: 200) menyatakan bahwa daya ledak merupakan faktor utama dalam pelaksanaan segala macam keterampilan gerak berbagai cabang olahraga, karena daya ledak adalah kemampuan untuk mengerahkan kekuatan maksimal dalam waktu yang sangat cepat. Menurut Sukirno (2012: 37) pelari sprint, selain diperlukan kecepatan tinggi juga diperlukan jarak langkah, kekuatan, power otot tungkai, frekuensi langkah, koordinasi teknik, kelentukan (flexsibility), dan daya tahan anaerobik, kesemuanya merupakan komponen yang harus dipenuhi oleh seorang pelari sprint, untuk menghasilkan kecepatan yang tinggi. Hasil $r=-0,09$ atau $9 \%$ menunjukkan hubungan yang sangat lemah atau tidak signifikan antara daya ledak dengan lari sprint 100 meter.
Hubungan Panjang Tungkai dan Daya Ledak Otot Tungkai Dengan Hasil Lari Sprint 100 meter

Hubungan panjang tungkai dan daya ledak otot tungkai dengan lari sprint 100 meter dapat diinterpretasikan dengan mengukur koefisien korelasi ( $r$ ) nya. Besar koefisien korelasi antara panjang tungkai dan daya ledak otot tungkai dengan lari sprint 100 meter adalah sebesar $r=0,27$ atau $27 \%$, termasuk dalam kategori tingkat hubungan yang lemah. Berarti ada kontribusi hubungan antara panjang tungkai dan daya ledak otot tungkai dengan lari sprint 100 meter pada siswa putra SMP Negeri 1 Indralaya meskipun kontribusinya lemah. Harga $r$ bernilai positif, dengan demikian semakin panjang tungkai seseorang dan semakin besar daya ledak otot tungkai akan memberikan kontribusi lari sprint 100 meter.

Sampel dalam penelitian ini bukan siswa yang mengikuti ekstrakurikuler. Pada saat penelitian, terdapat beberapa siswa memiliki tungkai yang panjang namun kecepatan larinya masih lemah, daya ledak yang baik namun ketika mereka berlari hasilnya kurang memuaskan. Faktor yang menyebabkan adalah kecepatan reaksi siswa pada saat start masih lemah, siswa sering terlambat berlari saat aba-aba yak selesai. Selain itu daya tahan an aerobik siswa masih rendah hal ini dapat dilihat setelah siswa melewati jarak lebih dari 50 meter kecepatan larinya berkurang.

\section{PENUTUP}

\section{Simpulan}

Berdasarkan hasil penelitian ini dapat disimpulkan bahwa ada hubungan yang tidak signifikan pada panjang tungkai dan daya ledak otot tungkai dengan hasil lari sprint 100 meter pada siswa putra kelas VII di SMP Negeri 1 Indralaya.

\section{Saran}

Bagi peneliti selanjutnya disarankan untuk menambahkan variabel lain yang 
berhubungan dengan hasil lari sprint 100 meter dan menggunakan sampel yang jumlahnya lebih banyak.

\section{Daftar Pustaka}

Dita, Sugiyanto, dan Syafrial. 2018. "Analisis Kemampuan Kids Athletics Pada Siswa Sekolah Dasar Di Kota Bengkulu”. Jurnal Kinestetik, Vol. 2 (1)

Harsono.1988. Coaching Dan Aspek- Aspek Psikologis Dalam Coaching. Jakarta: Departemen Pendidikan dan Kebudayaan Direktorat Jendral Pendidikan Tinggi.

Nadisah.1991. Manusia dan Olahraga. Bandung: Universitas Pendidikan Indonesia.

Sudjana. 2005. Metoda Statistika. Bandung: Tarsito.

Sukirno. 2012. Dasar- Dasar Atletik dan Latihan Fisik. Palembang: Universitas Sriwijaya.

Syaripudin, Aib dan Muhadi. 1992. Pendidikan Jasmani dan Kesehatan. Jakarta: Departemen Pendidikan dan Kebudayaan Direktorat Jendral Pendidikan Tinggi. 